\title{
Histopathology of human American cutaneous leishmaniasis before and after treatment
}

\author{
Histopatologia de leishmaniose tegumentar americana \\ humana, antes e após o tratamento
}

\author{
A.C.C. Botelho, W.L. Tafuri, O. Genaro and W. Maụrink
}

\begin{abstract}
Chemical therapy for the treatment of leishmaniasis is still inadequate, and a number of drugs and therapeutic programs are being tested. Besides treatment, the ultimate goal is an effective cure, and histopathological analyses of the lesion cicatrices constitute an important measure of treatment success, or otherwise, in this respect. In this paper, we describe histopathological patterns in cases of American cutaneous leishmaniasis in 32 patients from the municipality of Caratinga, Minas Gerais, Brazil, before and after treatment with the following therapeutic methodos: I) leishvacin + glucantime; 2) leishvacin + BCG associated with glucantime; 3) glucantime; 4) leishvacin + BCG. Lesion fragments were collected from all patients by biopsy prior to, and approximately 30 days after, each treatment which resulted in a clinical diagnosis of cure. Following the analysis of slides, the preparations were described from a histopathological point of view and grouped taking into account the prevalence or significance of the characteristic elements. This process resulted in the following classification: 1. exsudative reaction (ER); 2. exsudative giant cell reaction (EGCR); 3. exsudative productive reaction (EPR); 4. exsudative productive giant cell reaction (EPGCR); 5. exsudative productive necrotic reaction (EPNR); 6. necrotic exsudative reaction (NER); 7. productive exsudative reaction (PER), 8. productive giant cell reaction (PGCR); 9. productive exsudative giant cell reaction (PEGCR); 10. productive exsudative giant cell granulomatous reaction (PEGCGR); 11. productive reaction (PR) and 12. productive cicatricial (cure) reaction (PCR). After this analysis, it was noted that clinical cure did not always coincide with histopathological cure.
\end{abstract}

Key-words: Cutaneous leishmaniasis. Histopathology. Treatment. Criteria for cure.

Resumo A quimioterapia para a leishmaniose não é satisfatória e existem hoje, várias drogas e esquemas terapêuticos em teste. Além do tratamento ideal, busca-se um critério de cura efetivo, onde a análise da histopatologia da cicatriz poderá ser de grande valia. Este trabalho propõe caracterizar o padrão histopatológico de casos humanos de leishmaniose tegumentar americana, em 32 pacientes do município de Caratinga-MG, antes e após o tratamento com os seguintes métodos terapêuticos: 1) leishvacin + glucantime; 2) leishvacin + BCG associado ao glucantime; 3) glucantime; 4) leishvacin + BCG. Foram colhidos fragmentos das lesões de todos os pacientes, através de biópsias, antes e após o tratamento, com diagnóstico de cura. Após análise das lâminas, as preparações foram descritas, do ponto de vista histopatológico, e agrupadas levando em conta a prevalência e a significância do elemento característico. Tal processo resultou na classificação: 1. reação exsudativa; 2. reação exsudativa giganto-celular; 3. reação exsudativa produtiva; 4. reação exsudativa produtiva giganto-celular; 5. reação exsudativa produtiva necrótica; 6. reação necrótica exsudativa; 7. reação produtiva exsudativa; 8. reação produtiva giganto-celular; 9. reação produtiva exsudativa giganto-celular; 10. reação produtiva exsudativa giganto-celular granulomatosa; 11. reação produtiva e 12. reação produtiva cicatricial (cura histopatológica). Observamos após tal análise, que nem sempre a cura clínica coincide com a cura histopatológica.

Palavras-chaves: Leishmaniose cutânea. Histopatologia. Tratamentos. Critérios de cura.

Departamento de Parasitologia, Instituto de Ciências Biologicas, Universidade Federal de Minas Gerais, Belo Horizonte, MG, Brasil.

Address to: Prof a A.C.C. Botelho. Deptํำ de Parasitologia/ICB/UFMG. Av. Antonio Carlos 6627, Pampulha, 31270-901 Belo Horizonte, MG. Fax (031) 441-6909.

Recebido para publicação em 06/03/97. 
Leishmaniasis is a disease caused by a digenetic protozoan of the genus Leishmania Ross, 1903, which infects vertebrate hosts of a number of mammalian species, including humans, and invertebrate hosts, which in the New World are insects of the genus Lutzomyia. It is a disease which has a wide spectrum of clinical manifestations. In this paper we deal with the cutaneous form, referred to as american cutaneous leishmaniasis (ACL).

The introduction of the use of Tartar Emetic by the Brazilian physician Gaspar Viana in 1912 was an important advance in the treatment of leishmaniasis. However, due to its toxicity and the frequent relapse it has been substituted by the use of pentavalent antimony, used to the present day. Antimony, although less toxic, is still problematic and its use is not encouraged in cases such as cardiopathic and nephropathic patients nor for the aged or during pregnancy.

Besides the search for the most effective drugs and therapy for leishmaniasis, it is necessary to establish accurate criteria for evaluating its cure. Most authors have adopted clinical criteria based on the complete healing of the lesion. However, in 1915, D'ultra e Silva4 observed that the closing up of the lesion was not sufficient evidence for a complete cure. Perhaps agreeing with this finding, Schubach 16 found leishmaniasis to be still present in a lesion which had healed over eight years previously. Likewise, Guerra5 not found the parasite in unaltered nasal mucous membranes in 147 patients with no history of leishmaniasis, but the intradermal test was positive in $21,8 \%$ showing a subclinical infection. Marsden 10 also recorded that some patients were still infected despite a clinical diagnosis declaring them cured. These findings underline the importance of histopathological studies of leishmaniasis, not only as an aid to diagnosis but also in the establishment of criteria to determine the success, or otherwise, of therapy.

Histopathological studies of leishmaniasis begun in Brazil when the disease was first identified in the country, and since then have worked towards establishing the characteristic morphological patterns of the disease. The first histopathological classification was suggested by Azulay 1 . Investigating cases of Old World diffuse leishmaniasis, Bryceson 3 proposed a classification of six histopathological groupings. Nicolis 13 , also studying forms of Old World leishmaniasis, proposed a simplified scheme with three histopathological phases. Ridley 15 , relating 60 biopsies with the prognosis of the lesions, proposed a classification of five groups, but later, added sub-groups which made the scheme difficult to use. Magalhães 6 studied 487 skin fragments of patients from Três Braços, in the State of Bahia, Brazil, and, while taking into account previous classifications, proposed his own of three groups. Magalhães 7 subsequently recommended a five group classification based on 162 skin fragments, and their correspondence with the clinical evolution of the disease which the author considered relevant in aiding doctors in their diagnosis and treatment. In another paper published the same year, Magalhães8 classified a further 378 biopsies of ACL carriers from the region of Três Braços into his five groupings of histopathological patterns. Finally Bittencourt and Barral2, taking into account the work of Ridley 15 and Magalhães7 8; proposed a simplified classification of just three patterns.

Based on this literature, we describe here our findings concerning the histopathology of skin fragments of patients from the municipality of Caratinga, in the State of Minas Gerais, Brazil, both before and after medical treatment, and characterize alterations in the basic histopathology and the evolution of the leishmaniasis lesion. We also analyze the processes involved in the cure of each of the therapeutic schemes under consideration.

We consider this study justifiable in that, as far we know, no systematic histopathological study of the leishmaniotic lesion has been carried out before and after treatment with four different therapeutic methods, with the additional aim of carrying out a comparative study of the development of the lesions and the kinetics of their cure. This enabled us to associate the clinical signs of cure with the histopathological aspects of the healed lesion, by comparing descriptions of the histopathological patterns with the respective treatments applied.

\section{MATERIALS AND METHODS}

This study was carried out with patients from the municipality of Caratinga, State of Minas Gerais, where a clinic is maintained specifically for the treatment of leishmaniasis, and which works in collaboration with the Sector of Leishmaniasis, Parasitology Department, Federal University of Minas Gerais (UFMG), Belo Horizonte. Skin fragments, obtained by biopsy, of 32 patients, before and after treatment, 
were studied. Scars were biopsied on various dates, most usually 30 days after patients were considered clinically cured.

Diagnosis was made by a direct smear stained with Giemsa, and by the Montenegro test. The fragments were subjected to routine histological processing. The material was separated into four groups, according to the treatments given: group I- leishvacin + glucantime; group IIleishvacin + BCG associated with glucantime; group III- glucantime; group IV- leishvacin + BCG.

Leishvacin is a leishmaniasis vaccine developed in the Department of Parasitology, UFMG (Mayrink11 12). It is a mixture of extracts of five dead, sonicated dermatotrophic strains of Leishmania: L. (L.) mexicana (MHOM/BR/60/BH6); L. L. amazonensis (IFLA/BR/67/PH8); L. L. sp (mexicana complex) (MHOM/BR/73/BH121); L.(L.) sp (L. major - like) (MHOM/BR/71/BH49); L. (Viannia) guyanensis (MHOM/BR/73/M1176). The protein concentration of leishvacin is $1500 \mu \mathrm{g} / \mathrm{ml}$.

Group I. Seven patients: two females and five males. The average age was 28 years, ranging from 12 to 42 . Most patients had only one lesion of an average duration of 75 days (range 45-90 days). In all patients the parasitological examinations were positive before treatment. Treatment: The vaccine was given by intramuscular injection according to the scheme of Mayrink12: Day $1-100 \mu l$, Day $2-200 \mu l$, Day $3-300 \mu$,

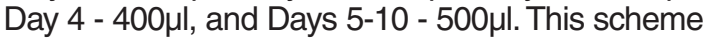
was repeated after an interval of 10 days.

Glucantime was administered by intramuscular injection in daily doses of $0.5 \mathrm{ml} / 5 \mathrm{~kg}$ weight, not exceeding $5 \mathrm{ml} /$ day, and given at the same time as the leishvacin injection, also with an interval of 10 days between treatment sessions. Treatment of this group of patients varied between 48 and 150 days.

Group II. Eight patients: three females and five males. The average age was 36 years, ranging from 14 to 66 . Six patients presented just one lesion. The average duration of lesions was 90 days (range 30-180 days). In all patients, parasitological examinations were positive before treatment. Treatment: leishvacin + BCG in a single dose by intradermal injection. Fifteen days later, glucantime was given, by intramuscular injection at a daily dose of $1 \mathrm{ml} / 5 \mathrm{~kg}$ weight, not exceeding $10 \mathrm{ml} /$ day, for 10 days, followed by a treatment interval of 10 days. The protein concentration of the vaccine was $600 \mu \mathrm{g} / 0.2 \mathrm{ml}$. The treatment period for this group varied between 43 and 108 days.

Group III. Eight patients: five females, three males. The average age was 39 years, ranging from 13 to 64 . Seven of the patients had only one lesion. The average duration of lesions was 118.5 days (range 38-210). In three patients the parasitological examinations were proved negative before treatment. Treatment: glucantime was administered by intramuscular injection in daily doses of $1 \mathrm{ml} / 5 \mathrm{~kg}$, not exceeding $10 \mathrm{ml} /$ day, for 10 days, with treatment intervals of 10 days. The treatment period for this group was $30-110$ days.

Group IV. Nine patients: three females, six males. The average age was 20 years, ranging from 3 to 56. Six patients presented with only one lesion. The average duration of lesions before treatment was 79.4 days (range 40-180). In one patient the parasitological examination proved negative prior to treatment. Treatment:

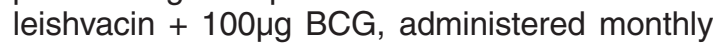
until a clinical diagnosis of cure or up to a maximum of five months. The protein concentration of the leishvacin in this group was $600 \mu \mathrm{g} / 0.2 \mathrm{ml}$. In this group, treatment lasted 34 to 138 days.

The criteria used to access successful treatment (cure) were clinical: complete healing of lesions.

In all groups, each "series" (period of administration of treatment + intervals: see Table 1) were repeated until a patient was considered clinically cured.

\section{RESULTS}

The combined qualitative analyses of biopsies before treatment can be summarized as follows: 1) Epidermis: discrete and accentuated hyperkeratosis. parakeratosis and papilomatosis. Acanthosis generally accentuated. Horn pearls or keratin plugs. Vacuolization of the basal cell layer, and Malpighian and granulous layers, especially of the Malpighian layer; 2) Dermis: diffuse infiltration of lymphocytes and plasma cells or, in perivascular foci, a predominance of small lymphocytes and plasmocytes. Occasionally the presence of eosinophils and polymorphonuclear cells was noted. Frequent giant cells of the Langhans and foreign-body types were also observed, as was the presence of voluminous and foamy macrophages which in 
Table 1 - Treatment scheme for each therapeutic group.

\begin{tabular}{|c|c|}
\hline Patient & Series/Treatments \\
\hline \multicolumn{2}{|l|}{ Group I- leishvacin + glucantime } \\
\hline RHS & 4 series $/ 4,8 \mathrm{ml} \mathrm{Sb}+0,5 \mathrm{ml}$ VAC \\
\hline SAO & 5 series $/ 5,0 \mathrm{ml} \mathrm{Sb}+0,5 \mathrm{ml} \mathrm{VAC}$ \\
\hline JAA & 5 series $/ 5,0 \mathrm{ml} \mathrm{Sb}+0,5 \mathrm{ml} \mathrm{VAC}$ \\
\hline LRP & 4 series $/ 5,0 \mathrm{ml} \mathrm{Sb}+0,5 \mathrm{ml} \mathrm{VAC}$ \\
\hline DF & 3 series $/ 5,0 \mathrm{ml} \mathrm{Sb}+0,5 \mathrm{ml} \mathrm{VAC}$ \\
\hline GCFC & 8 series $/ 5,0 \mathrm{ml} \mathrm{Sb}+0,5 \mathrm{ml} \mathrm{VAC}$ \\
\hline$A B C$ & 7 series $/ 5,0 \mathrm{ml} \mathrm{Sb}+0,5 \mathrm{ml} \mathrm{VAC}$ \\
\hline \multicolumn{2}{|c|}{ Group II - leishvacin + BCG + glucantime } \\
\hline SEM & $\mathrm{VAC}+\mathrm{BCG}+4$ series $/ 9,0 \mathrm{ml} \mathrm{Sb}$ \\
\hline JÁ & $\mathrm{VAC}+\mathrm{BCG}+3$ series $/ 10 \mathrm{ml} \mathrm{Sb}$ \\
\hline AC & $\mathrm{VAC}+\mathrm{BCG}+3$ series $/ 10 \mathrm{ml} \mathrm{Sb}$ \\
\hline MGSE & $\mathrm{VAC}+\mathrm{BCG}+4$ series $/ 10 \mathrm{ml} \mathrm{Sb}$ \\
\hline JRC & $\mathrm{VAC}+\mathrm{BCG}+2$ series $/ 10 \mathrm{ml} \mathrm{Sb}$ \\
\hline CRS & $\mathrm{VAC}+\mathrm{BGC}+2$ series $/ 10 \mathrm{ml} \mathrm{Sb}$ \\
\hline JDM & $\mathrm{VAC}+\mathrm{BCG}+3$ series $/ 10 \mathrm{ml} \mathrm{Sb}$ \\
\hline FRS & $\mathrm{VAC}+\mathrm{BCG}+5$ series $/ 10 \mathrm{ml} \mathrm{Sb}$ \\
\hline \multicolumn{2}{|l|}{ Group III - glucantime } \\
\hline GLT & 4 series $/ 9,5 \mathrm{ml} \mathrm{Sb}$ \\
\hline JBS & 6 series $/ 10 \mathrm{ml} \mathrm{Sb}$ \\
\hline EMA & 4 series $/ 10 \mathrm{ml} \mathrm{Sb}$ \\
\hline MRJ & 2 series $/ 10 \mathrm{ml} \mathrm{Sb}$ \\
\hline CGL & 5 series $/ 10 \mathrm{ml} \mathrm{Sb}$ \\
\hline MCS & 5 series $/ 10 \mathrm{ml} \mathrm{Sb}$ \\
\hline JSL & 3 series $/ 10 \mathrm{ml} \mathrm{Sb}$ \\
\hline ERJ & 3 series $/ 10 \mathrm{ml} \mathrm{Sb}$ \\
\hline \multicolumn{2}{|l|}{ Group IV - leishvacin + BCG } \\
\hline SMS & 5 series/VAC + BCG \\
\hline LPSR & 3 series/VAC + BCG \\
\hline NAG & 4 series/VAC + BCG \\
\hline TCM & 3 series $/ V A C+B C G$ \\
\hline LGM & 3 series/VAC + BCG \\
\hline RAB & 2 series $/ V A C+B C G$ \\
\hline JNO & 5 series/VAC + BCG \\
\hline PRO & 4 series $/ V A C+B C G$ \\
\hline OMA & 4 series $/ V A C+B C G$ \\
\hline
\end{tabular}

two cases were associated with parasites. Necrotic areas were rare. A few cases showed granulomatous reactions. Accentuated vascular neoformation. Collagen bundle neoformation, with broad and irregular fibers, sometimes disassociated. (Figure 1).

After treatment the principal alterations were 1) epidermis: persistence of hyperkeratosis, but less accentuated. Acanthosis, horn pearls and papilomatosis persisted in some cases. Persistence of the vacuolization of the cells of the Malpighian layer. 2) dermis: mononuclear exsudation, predominantly perivascular in multiple foci of variable intensity. The predominance of lymphocytes, and the presence of giant cells of the Langhans and foreign body types persisted. Capillary neoformation was of variable intensity (discrete and pronounced). Intense collagen neoformation, with fibers oriented in various directions or in one direction, and others uniformly oriented parallel to the basal epidermis, - or otherwise thick, poorly oriented, hyalinized, and located in the deepest part of the dermis. Typical granulomas were found extremely rare (Figure 2).

Following a complete and systematic analysis of all the slides to provide better understanding of lesion dynamics, we conventionally classified the inflammatory process by the prevalance and significance of the phenomena under consideration into 12 developmental phases (Table 2): 


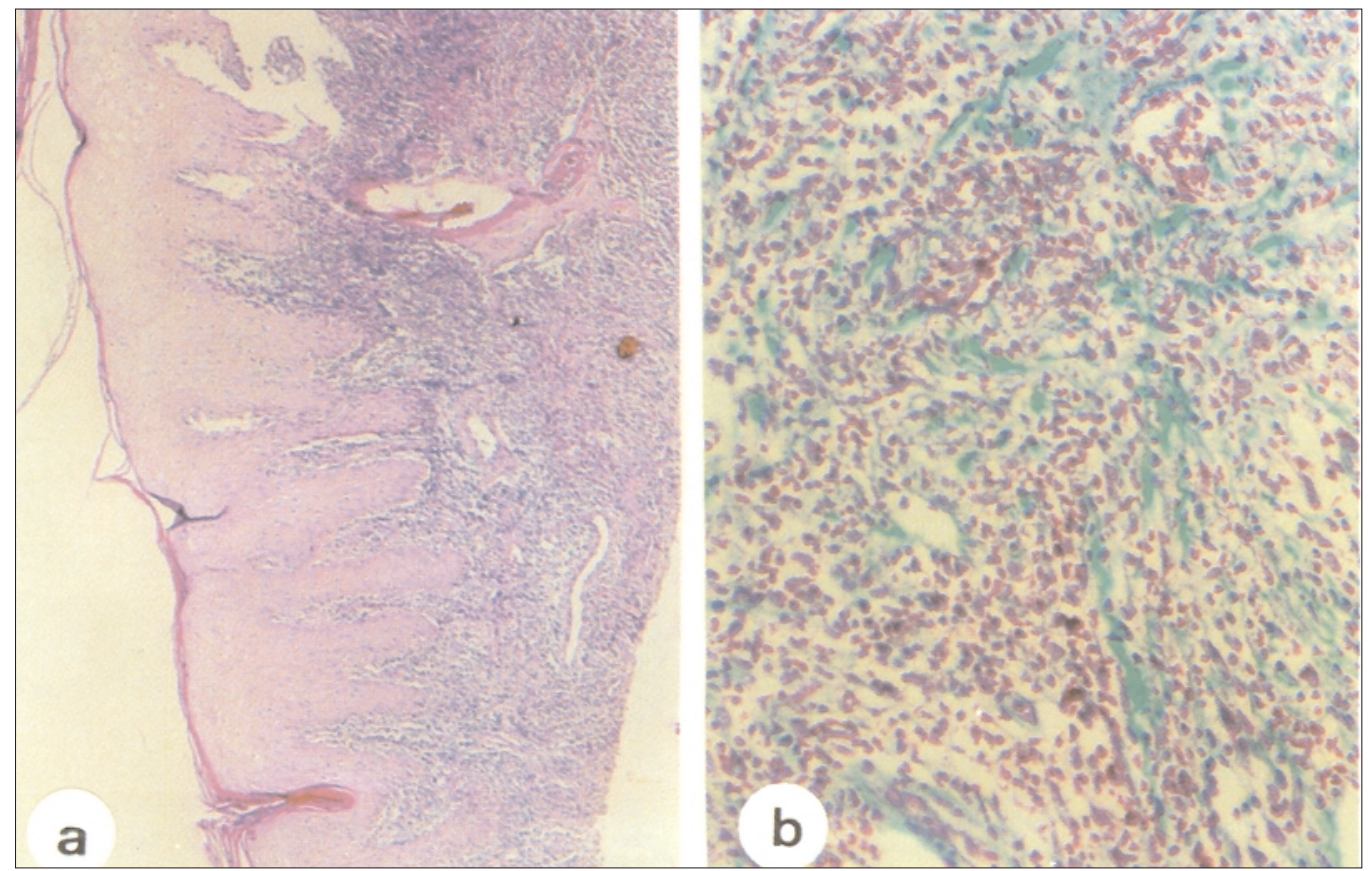

Figure 1 - a,b: skin of the ankle of patient $A B C$, taken before treatment. Intense diffuse exsudation. Infiltrate of lymphocytes and plasma cells on the superficial dermis. Papillomatosis, hyperkeratosis and parakeratosis. (a) HE 40x, (b) Tricrômico de Gomori 200x.
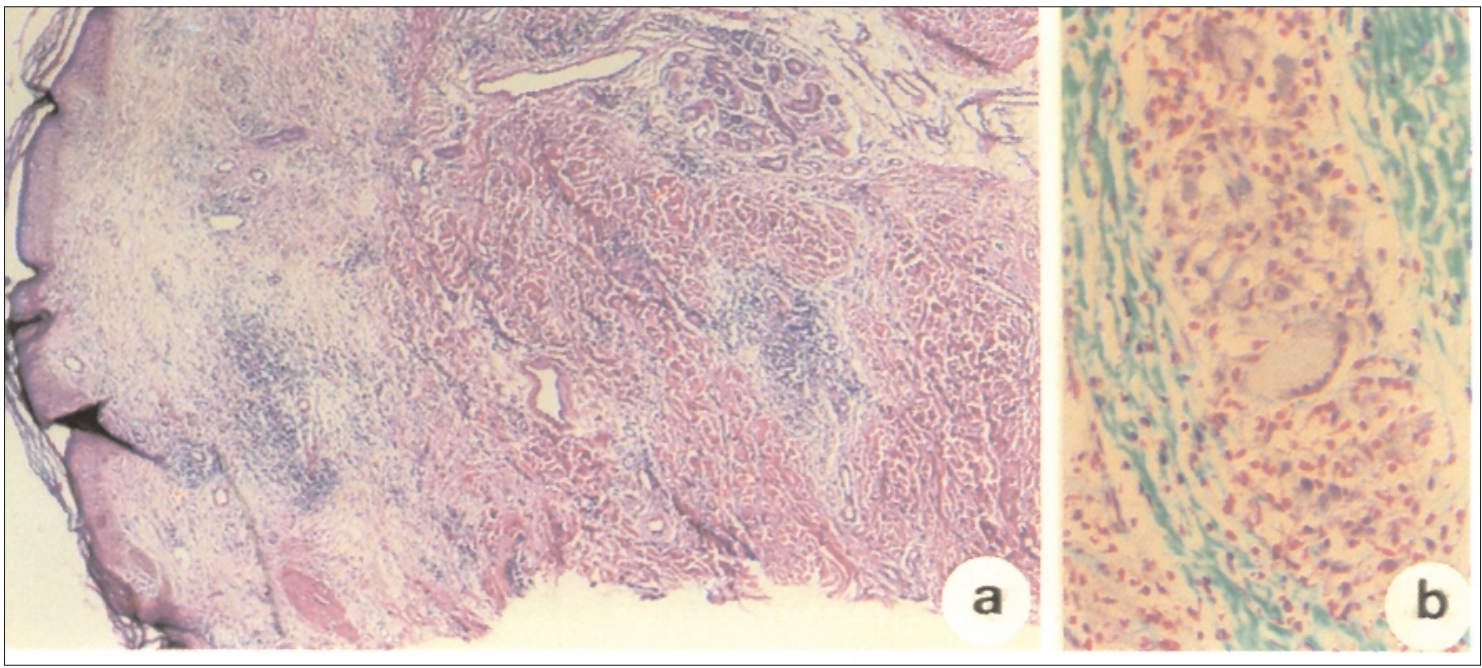

Figure 2 - Skin of the leg (thigh) of patient JDM after treatment and clinically cured. (a) Discrete chronic inflammatory infiltration, mainly perivascular, on the superficial and deep dermis. Collagen neoformation in various directions. (b) Granulomas with Langhans cells and collagen neoformation. (a) HE 40x, (b) Tricrômico de Gomori 200x. 
1. exsudative reaction (ER); 2. exsudative giant cell reaction (EGCR); 3. exsudative productive reaction (EPR); 4. exsudative productive giant cell reaction (EPGCR); 5 . exsudative productive necrotic reaction (EPNR); 6. necrotic exsudative reaction (NER); 7. productive exsudative reaction (PER); 8. productive giant cell reaction (PGCR); 9. productive exsudative giant cell reaction (PEGCR); 10. productive exsudative giant cell granulomatous reaction (PEGCGR); 11. productive reaction (PR); 12. productive cicatricial (cure) reaction (PCR).
The non-parametric Kruskall-Wallis test was used for the statistical analysis of the results in which values were attributed to the histopathological findings before and after treatment. The numbers applied after treatment were subtracted from those before treatment. The resulting value eliminated differences between the initial clinical situation of each patient (Table 2). The results showed that there was no significant statistical difference between the four treatments in the process towards cure $\left(\chi^{2}=7.815, \mathrm{~T}=1.537, \mathrm{~T}<\chi^{2}\right)$.

Table 2 - Main histopathological characteristics shown by the patients before (BT) and after treatment (AT) for each therapeutic group.

\begin{tabular}{|c|c|c|c|c|c|c|c|}
\hline \multirow[t]{2}{*}{ Patient } & \multicolumn{2}{|c|}{ Inflammatory process } & \multirow{2}{*}{$\frac{\text { Difference }}{\text { BT-AT }}$} & \multicolumn{2}{|c|}{ Granuloma } & \multicolumn{2}{|c|}{ Giant cells } \\
\hline & BT & AT & & $\overline{\mathrm{BT}}$ & AT & BT & AT \\
\hline \multicolumn{8}{|c|}{ Group I - leishvacin + glucantime } \\
\hline RHS & NER & PEGCR & 3 & - & TF & - & $\mathrm{L}$ \\
\hline SAO & ER & PCR & 11 & - & - & - & - \\
\hline JAA & EPGCR & PCR & 8 & - & - & $\mathrm{L}$ & - \\
\hline LRP & EPNR & PR & 6 & - & - & - & - \\
\hline DF & EPR & EPR & 0 & - & - & - & - \\
\hline GCFC & EPR & PCR & 9 & - & - & - & - \\
\hline$A B C$ & NER & PGCR & 2 & - & - & - & FB \\
\hline \multicolumn{8}{|c|}{ Group II- leishvacin + BCG + glucantime } \\
\hline SEM & NER & PCR & 6 & - & - & - & - \\
\hline JA & EPR & PR & 8 & - & - & - & - \\
\hline $\mathrm{AC}$ & EPR & PER & 4 & - & - & - & - \\
\hline MGSE & ER & PCR & 9 & - & - & - & - \\
\hline JRC & EPGCR & EPGCR & 0 & - & - & $\mathrm{L}$ & L, FB \\
\hline CRS & EPR & EPGCR & 1 & - & TF & - & $\mathrm{L}$ \\
\hline JDM & EPGCR & EPGCR & 0 & TF & - & $\mathrm{L}, \mathrm{FB}$ & $\mathrm{L}$ \\
\hline FRS & ER & PER & 6 & - & - & - & - \\
\hline \multicolumn{8}{|c|}{ Group III - glucantime } \\
\hline GLT & ER & PCR & 11 & - & - & - & - \\
\hline JBS & ER & PER & 6 & - & - & - & - \\
\hline EMA & EPR & PR & 8 & - & - & - & - \\
\hline MRJ & ER & PEGCR & 8 & - & TF & - & $\mathrm{L}$ \\
\hline CGL & EGCR & PEGCG & 8 & - & + & $\mathrm{L}$ & $\mathrm{L}, \mathrm{FB}$ \\
\hline MCS & EPR & PR & 8 & - & - & - & - \\
\hline JSL & EPR & EPR & 0 & - & - & - & - \\
\hline ERJ & EGCR & EPR & 1 & TF & - & $\mathrm{L}$ & - \\
\hline \multicolumn{8}{|c|}{ Group IV - leishvacin + BCG } \\
\hline SMS & EPGCR & PER & 3 & - & - & $\mathrm{L}$ & - \\
\hline LPSR & EPGCR & PEGCR & 5 & - & + & $\mathrm{L}$ & $\mathrm{L}, \mathrm{FB}$ \\
\hline NAG & EPR & PER & 4 & - & - & - & - \\
\hline TCM & EPR & PEGCGR & 7 & - & NTF & - & $\mathrm{L}$ \\
\hline LGM & EPGCR & PEGCGR & 6 & - & + & L & $\mathrm{L}$ \\
\hline RAB & ER & EPR & 2 & - & - & - & - \\
\hline JNO & ER & EPGCR & 3 & - & + & - & $\mathrm{L}, \mathrm{FB}$ \\
\hline PRO & ER & PER & 6 & - & - & - & - \\
\hline OMA & ER & PR & 10 & - & - & - & - \\
\hline \multicolumn{8}{|c|}{$\begin{array}{l}\text { Exsudative Reaction (ER); Exsudative Giant Cell Reaction (EGCR); Exsudative Productive Reaction (EPR); Exsudative } \\
\text { Productive Giant Cell Reaction (EPGCR); Exsudative Productive Necrotic Reaction (EPNR); Necrotic Exsudative Reaction } \\
\text { (NER); Productive Exsudative Reaction (PER); Productive Giant Cell Reaction (PGCR); Productive Exsudative Giant Cell } \\
\text { Reaction (PEGCR); Productive Exsudative Giant Cell Granulomatous Reaction (PEGCGR); Productive Reaction (PR); } \\
\text { Productive Cicatricial (cure) Reaction (PCR) }\end{array}$} \\
\hline$=$ pres & $\mathrm{e}, \mathrm{TF}=\mathrm{t}$ & cy to forn & VTF $=$ not & & & & \\
\hline
\end{tabular}


Differences between treatments in the rate of cure were also tested (Kruskall-Wallis applied to the number of series/treatment) and likewise were not significant $\left(\chi^{2}=7.815, T=5.538\right.$, $\left.\mathrm{T}<\chi^{2}\right)$.

\section{DISCUSSION}

The association between the lesion histopathology and the disappearance of leishmania parasites has been studied by a number of authors, identifying patterns in the evolution of the lesions or correlating them with the clinical situation and the immunological response. Observation of the histopathological picture before and after treatment, could allow us to say that a clinical cure of a patient was accompanied by an evolution of histopathological cure. However, the two did not always coincide. The number of series/treatment was not always directly proportional to the picture in terms of a histopathological cure. The ideal cure should involve both a clinical and histopathological cure, and studies of the latter cannot only aid diagnosis but can also be used as a criterion of cure.

In Group I, we observed coincident clinical and histopathological cures in three patients, and a histopathological picture with an active exsudative process even after the clinical cure was most pronounced in three patients.

In Group II, a clinical cure coincided with histopathological cure in two patients, and an active exsudative process, even after a clinical cure, was very marked in five patients.

In Group III, a clinical cure coincided with a histopathological cure in only one patient; there was recrudescence in one, and no coincidence in three patients.

In Group IV, none of the patients showed coincidence between clinical and histopathological assessment of cure. One patient was close to achieving this, but active exsudative processes after a clinical cure were notable in six patients.

There was no significant statistical difference between the four treatments in the evolution of the cure, or in the time taken to achieve it.

The patients studied are still being accompanied and only one (Group III) showed relapse five months after being considered clinically cured. In the first treatment, the patient received three series of glucantime, but remained with an exsudative productive reation (EPR-3). Treatment after recrudescence involved three more glucantine series, and the final histopathological picture was of productive reaction (PR-11).

Schubach 16 recorded a case of a patient treated in 1979, who, when re-examined in 1987, showed a biopsy culture of the cicatrices which was positive for Leishmania sp. As a result, we carried out scar tissue cultures for three patients, 383, 273, and 242 days after the last dose of treatment, respectively. In all the three cases leishmania parasites were not detected.

The aim of the classification adopted herein was to verify the process of lesion healing, from the beginning of treatment until the anatomical/clinical diagnosis of cure. For this reason we did not follow the schemes of Ridley ${ }^{14}$, Magalhães 67 and Bittencourt2.

Ridley 14 reported usually successful prognoses in cases with necrotic foci in the central area of the lesion. In the cases described herein four showed some foci of necrosis before treatment, but, in each of these cases, clinical cure was achieved.

Twenty-eight of the 32 cases showed positive results for parasitological tests with smear stained with Giemsa, but parasites were observed in the histological sections of only two patients.

Knowing that the prevalent species in Caratinga is $L$. $b$. braziliensis 9 strains from three patients were characterized by isoenzymes. All three were infected with $L$. braziliensis.

These results confirm some observations made on scar biopsies of 20 patients analyzed by $\mathrm{Dr}$ Hugo Silviano Brandão (personal communication to W.M. in 1982), in which it was found that all cases showed inflammatory processes even after the patient had been released following a clinical diagnosis of cure; in addition all of them showed negative results in direct searches of parasites in histological sections.

Proliferative phenomena of the epidermis simulating epidermal carcinoma which can sometimes complicate differential diagnoses were not found in any of the patients studied here.

With respect to collagen and elastic turnover during the evolution of the inflammatory process, there were very large differences between patients. In general, the elastic fibers 
were progressively destroyed up to the moment when the cure was accompanied by fibrosis. The distribution, structure, orientation, and regressive phenomena of collagen were very similar to that of secondary repair cicatrices, although more retractible and proliferative.

\section{ACKNOWLEDGMENT}

To Prof Ivan Sampaio, Departamento de Zootecnia, Escola de Veterinária, Universidade Federal de Minas Gerais, for his help in the statistical analysis of the data.

\section{REFERENCES}

1. Azulay RD. Histopatologia da Leishmaniose Tegumentar. Dermatologia Ibero Latino-Americana 2:7-15,1960. Apud: Bittencourt AL, Barral A. Evaluation of histopathological classifications of American Cutaneous and Mucocutaneous Leishmaniasis. Memórias do Instituto Oswaldo Cruz 86: 51-56, 1991.

2. Bittencourt AL, Barral A. Evaluation of histopathological classifications of American Cutaneous and Mucocutaneous Leishmaniasis. Memórias do Instituto Oswaldo Cruz 86:51-56, 1991.

3. Bryceson ADM. Diffuse Cutaneous Leishmaniasis in Ethiopia. I. The clinical and histopathological features of the disease. Transactions of the Royal Society of Tropical Medicine and Hygiene 63:708-737, 1969.

4. D'ultra e Silva O. Sobre a Leishmaniose Tegumentar e seu tratamento. Memórias do Instituto Oswaldo Cruz 7:213-248, 1915.

5. Guerra MOP, Furtado T, Barros GC, Sessa, PA, Carias VRD. Infecção subclínica na Leishmaniose Tegumentar Americana. Anais Brasileiros de Dermatologia 60: 365-369, 1985.

6. Magalhães AV, Llanos A, Cuba CC, Araujo FB, Parreiras BM, Medeiros JM, Barreto AC, Marsden PD, Raick NA. Nova classificação histopatológica da Leishmaniose Tegumentar. In: Sociedade Brasileira de Patologistas (ed) Anais do VI Congreso Regional Centro-Leste da Sociedade Brasleira de Patologistas, 3-6 Novembro, Imprensa Universitária, Uberlandia, p. 62,1982.

7. Magalhães AV, Moraes MAP, Raick AN, LlanosCuentas A, Costa JML, Cuba CC, Marsden PD. Histopatologia da Leishmaniose Tegumentar por
Leishmania braziliensis braziliensis. 4. Classificação histopatológica. Revista do Instituto de Medicina Tropical de São Paulo 28:421-430, 1986a.

8. Magalhães AV, Moraes MAP, Raick AN, LlanosCuentas A, Costa JML, Cuba CC, Marsden PD. Histopatologia da Leishmaniose Tegumentar por Leishmania braziliensis braziliensis. 1. Padrões histopatológicos e estudo evolutivo das lesões. Revista do Instituto de Medicina Tropical de São Paulo 28:253-262, 1986b.

9. Magalhães-Rocha NM, Melo MN, Babá EH, Williams $P$, Dias M, Michalick MS, Costa CA, Mayrink W, Tavora PTC. Isoenzymatic characterization of Leishmania isolated from human hosts in the Rio Doce Valley - MG. Memórias do Instituto Oswaldo Cruz 82:96, 1987.

10. Marsden PD, Netto EM, Badaró R, Cuba CAC, Costa JLM, Barreto AC. Correspondence. The American Journal of Tropical Medicine and Hygiene 35:449, 1986.

11. Mayrink W, Costa CA, Magalhães PA, Melo MN, Dias M, Oliveira-Lima A, Michalick MSM, Williams P. A field trial of vaccine against American Dermal Leishmaniasis. Transactions of the Royal Society of Tropical Medicine and Hygiene 73:385-387, 1979.

12. Mayrink W, Michalick MSM, Melo MN, Nascimento E, Magalhães PA, Costa CA, Oliveira-Lima A, Dias M. Tratamento da Leishmaniose Tegumentar utilizando vacina. Anais Brasileiros de Dermatologia 6:55-59, 1991.

13. Nicolis GD, Tosca AD, Stratigos JD, Capetanakis JA. A clinical and histological study of cutaneous leishmaniasis. Acta Dermato-venereologica 58:521-525, 1978.

14. Ridley DS. Histopathogenic mechanisms in leishmaniasis. Pathologica 75:471-479, 1983.

15. Ridley DS, Marsden PD, Cuba CC, Barreto AC. A histological classification of mucocutaneous leishmaniasis in Brazil and its clinical evaluation. Transactions of the Royal Society of Tropical Medicine and Hygiene 74:508-514, 1980.

16. Schubach A, Marzochi M, Araujo ML, Conceição NF. Healed lesion of Cutaneous Leishmaniasis - a positive culture for Leishmania $s p$. in the scar tissue years after cure. Memórias do Instituto Oswaldo Cruz 82 (supl 1):64, 1987. 